
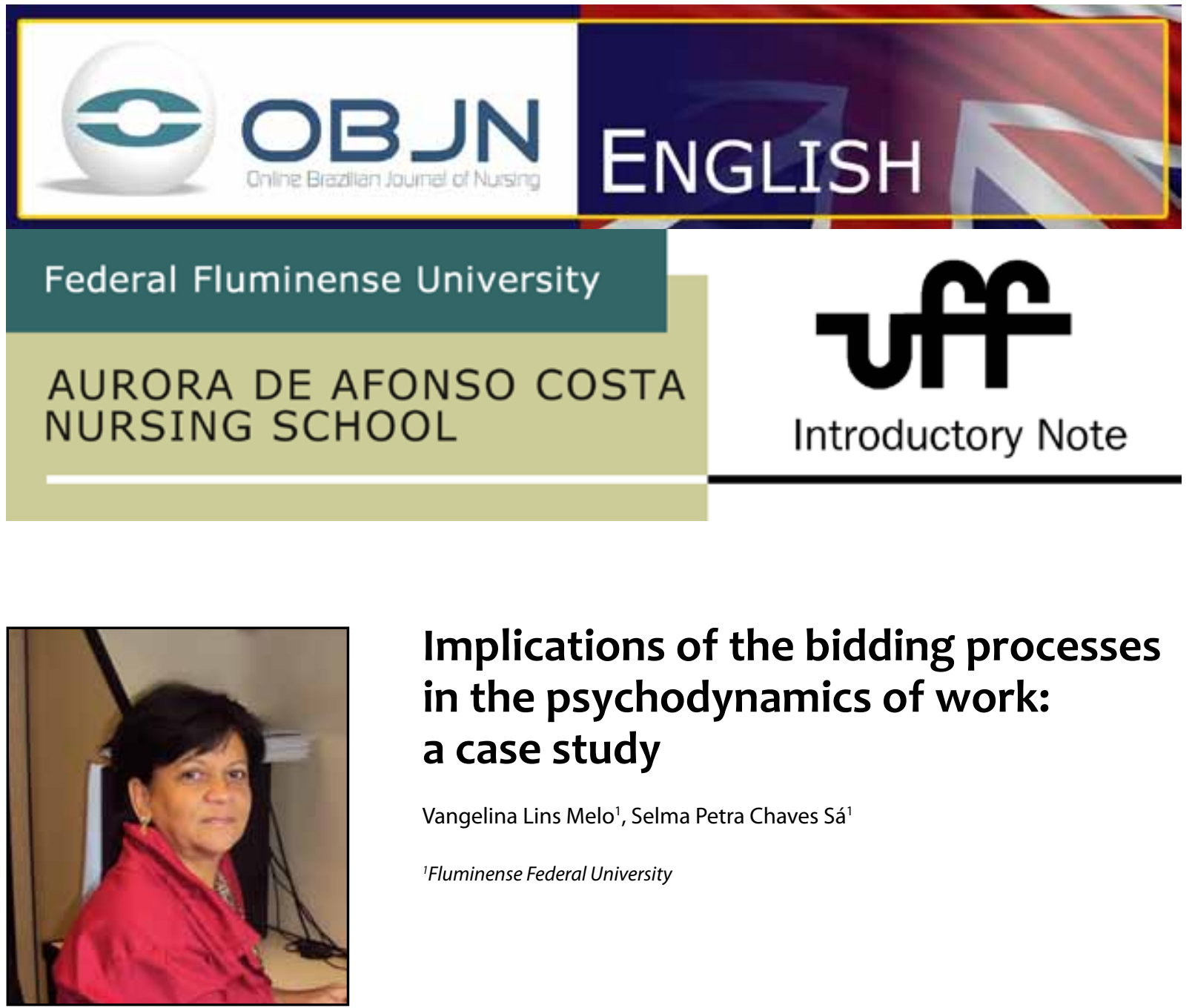

\title{
Implications of the bidding processes in the psychodynamics of work: a case study
}

Vangelina Lins Melo', Selma Petra Chaves Sá

${ }^{1}$ Fluminense Federal University

\section{ABSTRACT}

Introduction: When purchasing supplies and equipment for the use of workers of a Meal Producing Unit (MPU), the purchasing of products that interfere with the psychodynamics of work may occur as part of the bidding process, possibly causing workers to suffer. Aim: To analyze the relationship between the labor needs of workers of an MPU and the supplies and equipment acquired in a bidding, which affect the psychodynamics of work, in order to minimize the possible suffering of workers.

Method: A case study qualitative approach was used in this research that will be undertaken in Rio de Janeiro in 2013. The subjects of this study were the workers of an MPU of a university restaurant in Niterói, RJ, Brazil, who meet the inclusion criteria. Data collection: This will involve non-participative direct observation, individual structured interviews and photographic records. Alceste software will be used for the textual analysis, as well as Bardin's content analysis. The data will be compared to the Dejours' benchmark.

Descriptors: Pain; Competitive Bidding; Working Conditions, Collective Feeding. 


\section{PROBLEM SITUATION AND ITS SIGNIFICANCE}

In most countries, purchases made by governments are important instruments of public policy and economic development. The public sector is one of the largest consumers in the market, and government purchases are of particular relevance due to their weight in the world economy. They represent approximately $10 \%$ to $15 \%$ of the Gross Domestic Product (GDP) of the countries which participate in the World Trade Organization (WTO)(1).

In Brazil, in 2011, purchases and contracts made by the Public Administration at all levels of government corresponded to approximately $21 \%$ of GDP. They are considered factors that promote the boosting of the economy and national development ${ }^{(2)}$.

The government provides services such as defense, education and infrastructure. Similarly, investment has been observed in the university restaurant (UR) of the Fluminense Federal University (FFU), making possible the execution of bidding processes needed to develop policies to support the student body.

When considering the daily working conditions of workers of the Meals Producing Unit (MPU) at the university, the bidding processes also deserves attention, since several factors can lead to dissatisfaction in the workplace.

Studies show that workers are exposed to situations that may affect their health due to poor working conditions caused by environmental problems, industrial processes, and the use of equipment and supplies probably acquired through bids ${ }^{(3)}$.

One should be aware of what workers from an MPU say regarding the products purchased, as the involvement of those who use supplies and equipment purchased through a bidding process is essential.
This research reflects the concerns expressed by the employees regarding their working conditions due to the use of some unsuitable materials when it comes to performing their tasks.

It is essential for a study to address issues that could result in potential suffering in the everyday lives of workers in an MPU, in that such suffering may be subject to solutions as part of the bidding process.

In this research we will use the term suffering to designate physical distress caused by adverse working conditions, and creative suffering to refer to responses by which individuals create defensive strategies to protect themselves.

The study is relevant because it seeks to meet the expectations of the employees of an MPU. For the institution, this study may point to strategies leading to the best possible acquisitions without harming the quest for the lowest priced/best quality products.

The contribution to the nutrition profession will take the form of improvements in terms of acquisitions as part of the bidding process, reflected in better working and health conditions for the workers concerned.

\section{AIMS}

\section{General}

To analyze the relationship between the labor needs of workers from an MPU and the supplies and equipment acquired as a result of a bidding process. To consider the psychodynamics of work, aimed at minimizing the possible suffering of such workers.

Specific

To identify the supplies and equipment purchased for MPU/UR/FFU as part of a bidding 
process and which might lead to suffering in the workplace;

To describe the defense and/or creative mechanisms used by workers in terms of possible suffering related to materials and equipment acquired as part of the bid process used by the UR/FFU;

To relate the needs mentioned by workers to the influence of the materials purchased through the bidding process and used in their daily practices.

\section{METHOD}

This is a qualitative study that follows the methodological assumptions of a case study. In terms of data collection techniques, there will be direct non-participatory observation of the activities of workers, with a photographic record of the strategies used by them to minimize possible distress, as well as the use of individual semi-structured interviews. The interviews will be conducted using a questionnaire involving the collection of personal data together with questions to reveal the workers' needs. Scenario: UR/FFU, Gragoatá campus, Niterói, RJ, Brazil. Data will be collected in 2013. Research subjects: permanent university staff as well as employees of the subcontractors involved in the productive sector of restaurant meals/FFU, who meet the inclusion criteria, namely employees working directly in food production at the UR for over fourteen months. This will mean that they experienced the situation before the reopening of the restaurant, providing a comparison with current conditions. Of the 90 workers included in the study, the ones who decide to participate in the study will be asked to sign a consent form. ALCESTE software and Bardin's content analysis will be used for analytical purposes. The records from the observations, interviews and also the photographic records will be analyzed in order to find elements that meet the objectives of the study. The data will be triangulated and compared with Dejours' suffering concepts.

\section{REFERENCES}

1. Garcia VP. Políticas públicas nas compras governamentais. Netsaber Artigos [homepage on internet]. [cited 2012 ago 21]. Available from: http://artigos.netsaber.com.br/artigos_de_valdinei_pereira_garcia.

2. Instituto Brasileiro de Geografia e Estatística. [homepage on internet] Sala de imprensa. 2012[cited 2012 June 10]. Availble from: http:// www.ibge.gov.br/home/presidencia/noticias/ noticia_visualiza.php?id_noticia=2093.

3. Oliveira E.Pinel J.Gonçalves J.Diniz D. Nursing work in hospital emergency units - psychosocial risks: a descriptive study Online braz j nurs [Internet]. 2013 Mar [Cited 2013 June 12] 12(1):73-88. Available from: http://www.objnursing.uff.br/ index.php/nursing/article/view/4046. doi: http:// dx.doi.org/10.5935/1676-4285.20134046

Project data: Dissertation project of the Academic Master Program of Health Care Science, School of Nursing Aurora de Afonso Costa.

Advisor: Selma Petra Chaves Sá.

Financed by the researcher.

Approved by the Ethics Committee of the School of Medicine/FFU on 02/18/2013 No CAAE: 11437312.50000 .5243$.

AUTHORS

Vangelina Lins Melo: Participation in all stages of the research

Selma Petra Chaves Sá: Participation in all stages of the research

Received: 18/08/2013

Revised: 08/09/2013

Approved: 09/09/2013 